\title{
Taxonomic revision of the genus Oplognathus MacLeay, 1819 (Coleoptera: Scarabaeidae: Rutelinae: Rutelini)
}

\author{
Tamara G. CARVALHO ${ }^{\circledR 1, *}$, Matthias SEIDEL ${ }^{2} \&$ Paschoal C. GROSSI $^{3}$ \\ ${ }^{1,3}$ Programa de Pós-Graduação em Entomologia da UFRPE, Universidade Federal Rural de \\ Pernambuco, Rua Manoel de Medeiros, s/n - Dois Irmãos, 52171-900, Recife, PE, Brazil. \\ ${ }^{2}$ Centrum für Naturkunde (CeNak), Universität Hamburg, Martin-Luther-King-Platz 3, \\ 20146 Hamburg, Germany. \\ ${ }^{*}$ Corresponding author: lunatamaracarvalho@gmail.com \\ 2Email: matthias.seidel@uni-hamburg.de; matth.seidel@gmail.com \\ ${ }^{3}$ Email: paschoalgrossi@gmail.com \\ ${ }^{1}$ urn:lsid:zoobank.org:author:BFEF2E83-FB94-4DBF-85EE-00BBEC1703A5
${ }^{2}$ urn:1sid:zoobank.org:author:4DD9F954-99BB-49E9-AF45-D35E6D8903E3
${ }^{3}$ urn:lsid:zoobank.org:author:5347A9A1-F9DD-44E8-ABB8-2542E8EDF1FB
}

Abstract. The genus Oplognathus MacLeay, 1819 is revised based on type material of two of the three described species and scattered additional material from several collections around the world. The diagnostic characters of the genus are confirmed, distinguishing it from other Brazilian Areodina mainly by: quadrangular clypeus with trilobate apex in males, rounded in females, extending beyond labrum in both sexes; mandibles with three distinct teeth; maxillae with six teeth; antenna with 10 antennomeres; 10 elytral striae; mesoventral process present; and asymmetrical parameres. The genus and all three species are redescribed, and the female of Oplognathus bahianus Ohaus, 1912 is described for the first time. We consider Oplognathus helmenreichi var. maculicollis Ohaus, 1914 an unavailable infrasubspecific taxon that is conspecific with Oplognathus helmenreichi Ohaus, 1905; its distribution is updated, and the different spelling of the specific epithet is discussed. A neotype is designated for Oplognathus kirbii MacLeay, 1819 since the holotype is currently considered lost. Additionally, an identification key and a distribution map are included.

Keywords. Areodina, Brazil, Neotropical region, taxonomy.

Carvalho T.G., Seidel M. \& Grossi P.C. 2021. Taxonomic revision of the genus Oplognathus MacLeay, 1819 (Coleoptera: Scarabaeidae: Rutelinae: Rutelini). European Journal of Taxonomy 764: 62-84.

https://doi.org/10.5852/ejt.2021.764.1471

\section{Introduction}

Areodina Burmeister, 1844 (Rutelinae, Rutelini) has 11 genera, most with a New World distribution (Grossi \& Vaz-de-Mello 2015). Cotalpa Burmeister, 1844, Parabyrsopolis Ohaus, 1915, Parachrysina Bates, 1988, Paracotalpa Ohaus, 1915, Pseudocotalpa Hardy, 1971, and Viridimicus Jameson, 1990 are restricted to North and Central America. Areoda MacLeay, 1819, Byrsopolis Burmeister, 1844, Moronius 
Grossi \& Vaz-de-Mello, 2015 and Oplognathus MacLeay, 1819 are exclusive to South America; Areoda, Moronius and Oplognathus exclusive to Brazil (Ratcliffe \& Jameson 1989; Grossi \& Vaz-de-Mello 2015); while Xenoproctis Kolbe, 1986 is restricted to Africa (Jameson 1990).

Oplognathus is considered a rare genus with few specimens represented in collections, and as other areodines, represented by few species: Oplognathus bahianus Ohaus, 1912, O. helmenreichi Ohaus, 1905 and O. kirbii MacLeay, 1819 (MacLeay 1819; Ohaus 1934; Blackwelder 1944; Machatschke 1972; Krajcik 2007). Species of Oplognathus are distributed in the Brazilian Atlantic Forest, occurring from southern Bahia to northern Paraná states (Ratcliffe \& Jameson 1989). Most of the known specimens were collected in the $19^{\text {th }}$ and $20^{\text {th }}$ centuries, and there are very few recently collected specimens. In species of Oplognathus, the most peculiar diagnostic character of adults is the trilobed clypeus of males. In contrast, females can be easily confused with small females of Areoda. When describing Oplognathus for the first time, MacLeay (1819) pointed out the following characteristics: mandible with tridentate apex in the inner margin, maxillae with six teeth, labial palpi dorsally inserted on mentum, apex of mentum rounded, clypeus subquadrangular, short and trilobed. The biology of the genus is unknown, except for the report by Grossi \& Vaz-de-Mello (2015) of collecting of $O$. bahianus in light traps, indicating nocturnal habits.

Jameson (1990) presented the only up to date morphological phylogenetic analysis for Areodina. In her analysis the monophyly of the subtribe was confirmed and Oplognathus, Areoda and Byrsopolis formed a clade, sister group to the Central and North American genera clade. According to Carvalho \& Grossi (2018), Oplognathus and Areoda are differentiated by the presence of a forward-projecting mesoventral process, which is absent in both Byrsopolis and Moronius (hypothesizing that Moronius also belongs to this clade). According to Jameson (1990), Oplognathus differs from other Areodina because of three diagnostic characteristics: 1) clypeus ventrally produced beyond labrum, and with weakly trilobed apex in males; 2) presence of mesoventral process; and 3) asymmetrical parameres. However, the latter two characteristics are also observed in Areoda, but with a hook-like projection in parameres, the mesoventral process is relatively longer and the asymmetry of the parameres much more evident in Areoda. To a much lesser degree, such paramere asymmetry is also observed in Byrsopolis. The clypeus projecting beyond the labrum may be the best feature to distinguish among the three genera, a character present in both sexes.

In this present contribution we revise the genus Oplognathus based on external morphology. All species are included, and illustrations of the external morphology, the mouth parts, and the male genitalia are presented. A distribution map of the species is given for the first time, as well as an identification key for the three species of the genus.

\section{Material and methods}

\section{Taxonomic material}

A total of 37 adult specimens from 12 collections were studied, including type material found. The material examined in the present study is housed in the following collections:

CEIOC = Coleção Entomológica do Instituto Oswaldo Cruz, Rio de Janeiro, Brazil (Márcio Felix) [images only]

CEMT = Coleção Zoológica do Mato Grosso, Seção de Entomologia, Cuiabá, Brazil(Fernando Z. Vaz-de-Mello)

CERPE $=$ Coleção Entomológica da Universidade Federal Rural de Pernambuco, Recife, Brazil (Paschoal C. Grossi)

CMNC = Canadian Museum of Nature, Ottawa, Canada (François Génier) [images only]

EPGC $=$ Everardo and Paschoal Grossi Collection, Nova Friburgo, Brazil (Everardo J. Grossi)

IBSP $\quad=$ Coleção Adolph Hempel, Instituto Biológico de São Paulo, São Paulo, Brazil (Sergio Ide) 


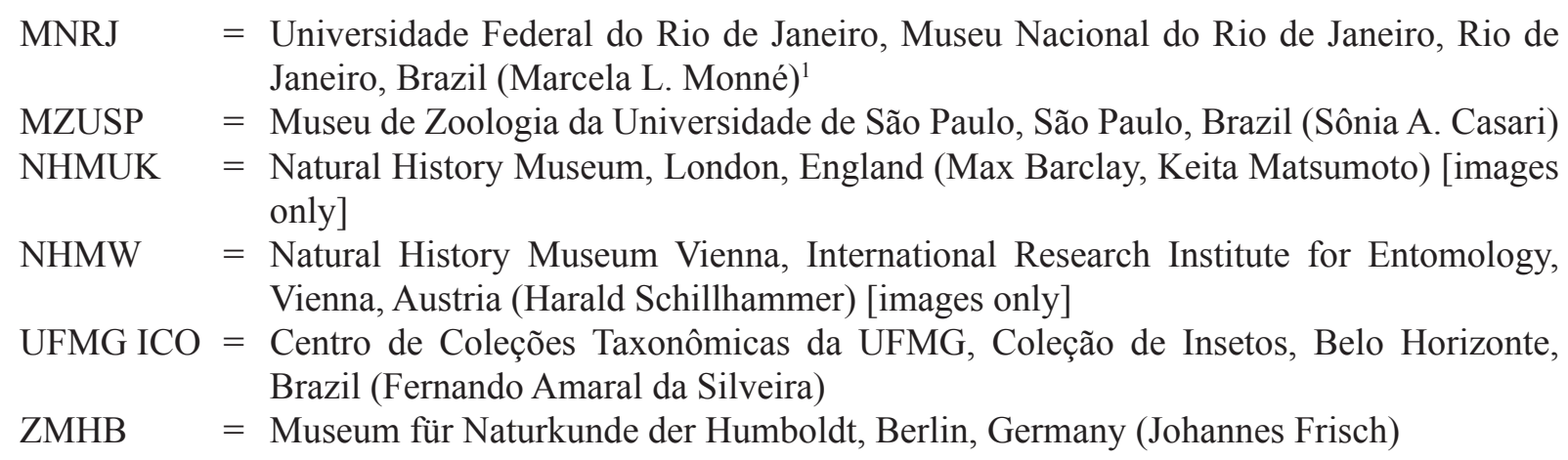

${ }^{1}$ In September 2018 a major fire destroyed 90\% of the museum's collection. Fortunately, all the specimens of Oplognathus supplied to us were on loan at the time of the accident. The material used in this work is safely preserved.

\section{Measurements}

Measurements were obtained with a pachymeter. The body length was measured from the apex of the head to end of the elytra. The body width was measured at the middle of the pronotum. The puncture size, and the density of punctures follow Jameson $(1990,1997)$, as well as the terminology used in this work. Redescriptions were made based on the types, the description of $O$. kirbii was made based on all specimens, the redescription of $O$. helmenreichi female and the description of $O$. bahianus female were based on one specimen only. The transcription of the type labels and the list of material examined follow the template recommended by the European Journal of Taxonomy, available at: $\mathrm{http}: / /$ sciencepress.mnhn.fr/sites/default/files/material_citations_formatting_guide.pdf

\section{Images}

Line drawings were made with a camera lucida attached on an Olympus SZX12 stereo microscope and digitized with a scanner. Photos of Oplognathus bahianus female and Oplognathus kirbii female were made with a Nikon D90 with a micro $40 \mathrm{~mm}$ lens attached, commanded by the software Helicon Remote, and mounted with the Combine Zp program. Neotype pictures of Oplognathus kirbii were provided to us by NHMUK, available at: https://www.flickr.com/photos/nhm_beetle_id/with/35547064990/. Matthias Seidel (CeNak), University Hamburg, Germany) made the dorsal habitus pictures of other specimens in this paper. Images were edited in GIMP ver. 2.8.

\section{Results}

Phylum Arthropoda Latreille, 1829

Class Insecta Linnaeus, 1758

Order Coleoptera Linnaeus, 1758

Superfamily Scarabaeoidea Latreille, 1802

Family Scarabaeidae Latreille, 1802

Subfamily Rutelinae MacLeay, 1819

Tribe Rutelini MacLeay, 1819

Subtribe Areodina Burmeister, 1844

Genus Oplognathus MacLeay, 1819

Oplognathus MacLeay, 1819: 159 (Fig. 1a-g).

Oplognathus - Latreille 1829: 553 (catalogue). — Laporte 1840: 124 (catalogue). - Machatschke 1970: 157 (synonymy observation); 1972: 5 (catalogue). — Ratcliffe \& Jameson 1989: 135 (general 
characterization). — Jameson 1990: 415 (phylogeny). — Krajcik 2007: 90 (catalogue). — Grossi \& Vaz-de-Mello 2015:221 (collecting report). —Carvalho \& Grossi 2018:369 (general characterization). Hoplognathus - Burmeister 1844: 428 (re-description). — Lacordaire 1856: 365 (catalogue). — Ohaus 1905: 322 (species description); 1912: 650 (species description); 1914a: 301 (species description); 1915: 257 (general characterization); 1918: 11 (catalogue); 1934: 41 (re-description). — Blackwelder 1944: 235 (catalogue).

\section{Type species}

Oplognathus kirbii MacLeay, 1819, by monotypy.

\section{Diagnosis}

Males with quadrangular, trilobate clypeus (Fig. 3a-d), rounded in females (Fig. 1b, e, g); clypeus extending beyond labrum in ventral view in both sexes; mandibles with three teeth in incisive area (Fig. 4a, e, i); maxillae with six teeth (Fig. 4b, f, j); antennae with 10 antennomeres (Fig. 3a-d); elytra with 10 striae (Fig. 1a-g); mesoventral process present (Fig. 8a-f); parameres asymmetrical (Figs 5-7), each paramere with two apical lobes, and one lateral projection.

\section{Redescription}

\section{Male}

Size. Total length: 17.4-22.4 mm; width across prothorax: $8.0-11.4 \mathrm{~mm}$.

CoLour. General aspect light yellow varying from yellowish to reddish metallic green, with golden and green reflexes; ventral surface metallic green; pronotum sometimes with black maculae; elytral margins metallic green or copper (Fig. 1a, c-d, f).

HEAD (Fig. 3). Reddish brown and/or metallic green. Clypeus subquadrate, surface rugose, setose, apex trilobate, apical and lateral margins elevated; clypeus produced beyond labrum in ventral view. Frontoclypeal suture usually distinct, straight or sinuous. Frons predominantly rectangular, surface glabrous, distinctly punctate, punctures dense; ocular canthus intruding a third of the eye's length, with scattered yellow setae. Labrum transverse, widely bilobed, setose, never visible from above. Mandibles laminar, rounded, intimately joined to labrum, with three incisive teeth (Fig. 4a, e, i). Maxillae setose, galea with six teeth, palpi 4-segmented, last palpomere longer than other three combined, varying from cylindrical to fusiform (Fig. $4 b-c, f-g, j, 1$ ). Mentum sinuous, bilobed or notched, ventral surface setose; labial palpus inserted dorsally on mentum, 3-segmented; last palpomere enlarged (Fig. $4 \mathrm{~d}, \mathrm{~h}, \mathrm{~m}$ ). Antenna with 10 antennomeres, antennal club 1.3 to $1.8 \times$ longer than antennomeres $2-7$ combined.

Thorax. Pronotum convex, transverse, about 1.8 times wider than longer, beaded; pronotal bead incomplete posteriorly at middle; surface varying from sparse to densely punctate; punctures small to moderate; maculae varying from two distinct anterolateral spots to two complete elongated maculae; some specimens with spots and maculae obsolete or absent. Each elytron with 10 distinctly punctate striae, punctures fine to moderate, interstriae almost smooth, punctures visible from $10 \times$ of magnification; humeri rounded, smooth; elytral apex straight. Hind wings full developed with a group of setae at AA $1+2$, setae long and fine, longer than width of first axillar sclerite; AP $3+4$ softly setose at base, with fine and minute setae; R $3+4$ sclerotized, disc with a distinct row of short setae. Mesoventral process acute, elongated, but never extended beyond anterior procoxal base (Fig. 8). Metafemur with anterior and posterior margins rounded, distinctly developed that other femora, with at least twice the mesofemoral width. Protibia tridentate, teeth reducing in size from apex to base, proximal tooth sometimes obsolete; inner apex with one tiny spur; ventral surface distinctly dilated, convex. Mesotibia with surface rugose, and two oblique carinae: proximal carina with 2-7 spinules, and distal carina with 
4-9 spinules, distal carina longer; mesotibial apex truncate with 7-13 spinules and two spurs, inner spur slightly longer. Metatibia wider than mesotibia, with inner margin distinctly rounded, apical spinules varying from 14-22; spurs distinctly short, and flattened, apex less acute than spinules; proximal carina with 2-8 spinules and distal carina with 6-11 spinules. Protarsomere V thickened; inner claw stronger with a basal obtuse tooth. Meso- and metatarsomere ornamented with lateral setae, and inner apical spinules. Meso- and metatarsal claws curved, simple, unequal in thickness; unguitractor plate present with two apical setae.

Abdomen. Pygidium flat to weakly convex, subtrapezoidal, transverse, surface rugose and setose; longer setae often on posterior sides. Ventrites metallic green, slightly convex, surface weakly punctate, punctures sparse, with scattered setae, sternites V and VI about twice as long as sternite IV. Parameres asymmetrical, each paramere with 1-2 distal lobes, left lateral expanded with a long projection, apical bifurcation wide, V-shaped (Figs 5-7).

Female (Fig. 1b, e, g)

Similar to male, differing in the following aspects:

Size. Total length: $17.2-22.1 \mathrm{~mm}$; width across prothorax: 7.5-11.1 mm.

HEAD. Apex rounded, never with projections; antennal club distinctly smaller.

Thorax. Pronotum more densely punctate. Elytra more convex, with dilated external margins, and elytral epipleuron wider in ventral view; legs thinner, anterior claws subequal, simple, not dilated.

Abdomen. Sternum and pygidium more convex.

\section{Distribution}

Brazil. Bahia: Condeúba; Espírito Santo: Palmital; Minas Gerais: Águas Vermelhas, Berizal, Manhumirim, Grão Mogol, Leme do Prado; Paraná: Curitiba; Rio de Janeiro: Rio de Janeiro; São Paulo: São Paulo (Fig. 9).

\section{Nomenclatural history}

Oplognathus was described by MacLeay (1819) without ' $\mathrm{H}$ ' at the beginning of the name, but later Burmeister (1844) redescribed the genus as "Hoplognathus", justifying that it would be the correct spelling for the name. Lacordaire (1856) also pointed the "error" of MacLeay, and uses Hoplognathus as a valid name, indicating "Aplognathus" as original wrong spelling, but not specifying the cause of the error. Since then, the name Hoplognathus has been widely used, including the description of the new species, generating more synonyms, such as Hoplognathus bahianus and Hoplognathus helmenreichi. Only Machatschke (1970) comments that Hoplognathus is a synonym, but when using Oplognathus, the spelling appears as "Oplongnathus". Already in his catalogue, Machatschke (1972) cites "Oplognathus" using the original spelling, which proves to be a typing error in the previous publications. Ratcliffe \& Jameson (1989) note this fact and show the correct use "Oplognathus MacLeay (not Hoplognathus as in Burmeister 1844; Ohaus 1918, 1934; Blackwelder 1944)", because according to Article 23 (ICZN 1999), the Principle of Priority, the oldest name should be used. In the original description, MacLeay (1819) does not detail the etymology of Oplognathus, but the Hoplo prefix, from the Greek Hoplon, means 'any tool or implement of armour and shield' while Gnathus, from the Greek, means 'mandible, mouth', possibly due to the distinct shape of the clypeus of the males. Perhaps, this explains the insistence of later authors (Burmeister 1844; Lacordaire 1856) to use the spelling Hoplognathus, instead of Oplognathus, as correct. However, as there is no written indication of this, and the addition of ' $\mathrm{H}$ ' is not a clear, obvious and necessary correction of the name, Oplognathus must be maintained, following the original description and not its subsequent spelling (ICZN 1999, Art. 33). 
Although Burmeister corrected the name of the genus, this does not mean that Ohaus intended to describe Oplognathus bahianus and Oplognathus helmenreichi in a genus other than Oplognathus. Thus, the author's name is written here without brackets, since the species is basically in its original combination.

Oplognathus kirbii was cited by Laporte (1840) as Oplognathus kirbyi and since then, both spellings were widely used, in addition to Hoplognathus kirbii and Hoplognathus kirbyi, it is common to find four spellings for this species throughout the literature. There are no details for replacing ' $i$ ' with ' $y$ ', but we can suppose Laporte (1840) to make this change on the assumption that MacLeay intended to honour the naturalist William Kirby. ICZN (1999, Article 58.2) states that the use of ' $i$ ' and ' $y$ ' are 'variant spellings' deemed to be identical. However, as MacLeay (1819) makes the description with no detail about etymology, it is prudent to keep the original spelling Oplognathus kirbii and not to use the subsequent spellings (ICZN 1999, Art. 33).

Oplognathus helmenreichi was described for the first time based on a single specimen in the collection of W.J.C. Weber by Ohaus (1905) with this spelling (for the specific epithet) and the locality Buenos Aires, Argentina. Later, Ohaus wrote that he found (Ohaus 1914a: 22) several specimens of this species in the Museum of Vienna, but he described them as a variety "var. maculicollis". These specimens were labelled "Helmr.", realizing that the name of the collector was Helmreichen and not Helmenreich, as published in Ohaus (1905). Although Ohaus (1914a) has described the variety as "Hoplognathus helmreicheni var. maculicollis" in the original publication, the correct name is Hoplognathus helmenreichi var. maculicollis (as written on the original label). In this case, Ohaus (1914a) made an unjustified emendation almost 10 years after the original publication of the species, not being recognized by the Code to validate a name (ICZN 1999, Art. 19.1, 33.2). Still, the latter spelling is used as valid, violating the Principle of Priority (ICZN 1999, Art. 23.9).

\section{Key to adult species of Oplognathus MacLeay, 1819}

1. Males with weakly trilobed clypeus, sides usually parallel; last maxillary palpomere cylindrical; mentum longer than wider, anterior margin sinuous; mesoventral process long (exceeding the anterior margin on mesocoxae, never exceeding the procoxae); (if female, clypeus rounded) ....... 2

- Males with strongly trilobed clypeus, sides clearly divergent (Fig. 3b); last maxillary palpomere fusiform (Fig. 4g); mentum as long as wide, anterior margin notched (Fig. 4h); mesoventral process short (not exceeding the anterior margin on mesocoxae), slightly flat (Fig. 8b, e); (if female, the clypeus rounded, and last maxillary palpomere cylindrical). Brazil: Bahia, Minas Gerais

O. bahianus Ohaus, 1912

2. Body distinctly bicoloured. Pronotum dark green with yellow maculae. Elytra reddish brown to orange yellow; size varying from $17.2 \mathrm{~mm}$ to $18.6 \mathrm{~mm}$ in length (Fig. 1c-e); anterior margin of mentum slightly sinuous (Fig. 4m); females without dilated epipleuron, simple. Brazil: Minas Gerais, Paraná

O. helmenreichi Ohaus, 1905

- Body colour uniformly yellowish golden, sometimes with spots or maculae on pronotum. Elytra golden yellow, with greenish reflections; size varying from $19.15 \mathrm{~mm}$ to $22.0 \mathrm{~mm}$ in length (Fig. 1ab); females with distinctly dilated epipleuron. Brazil: Espírito Santo; Minas Gerais; Paraná; Rio de Janeiro; São Paulo

O. kirbii MacLeay, 1819

Oplognathus kirbii MacLeay, 1819

Figs 1a-b, 2e, 3a, 4a-d, 5a-c, 7a-d, 8a, d, 9

Oplognathus kirbii MacLeay, 1819: 160.

Areoda kirbii-Dejean 1837: 172 (catalogue). — Guérin-Méneville 1844: 98, pl. 24 bis fig. 10 (catalogue). 
Oplognathus kirbyi - Laporte 1840: 124 (re-description). — Machatschke 1972: 5 (catalogue).

Hoplognathus kirbii - Burmeister 1844: 428 (re-description).

Hoplognathus kirbyi - Lacordaire 1856: 365 (catalogue). - Ohaus 1905: 322 (species diagnosis); 1912: 650 (species diagnosis); 1915: 257 (general characterization); 1918: 12 (catalogue); 1934: 42 (catalogue). — Blackwelder 1944: 235 (catalogue).

Oplognathus kirbii - Krajcik 2007: 90 (catalogue).

\section{Diagnosis}

Colour golden yellow with metallic green reflections; pronotum usually with two spots or elongate maculae (Figs 1a-b, 3a). Male with slightly trilobate clypeus (Fig. 3a); clypeus rounded in females, length of clypeus approximately $1.5 \times$ longer than length of frons; antennal club $1.3 \times$ longer than antennomeres 2-7 combined; last maxillary palpomere cylindrical in both sexes (Fig. 4c); mentum longer than wide, anterior margin sinuous, posterior angles distinctly acute (Fig. 4d). Pronotum with posterior border interrupted at middle, with scattered setae on maculae; epipleuron dilated on anterior half; mesoventral process acute (Fig. 8a, d); apex of mesotibia with 9-11 spinules; apex of the metatibia with 16-19 spinules; females with 9-10 and 18-23 spinules at the apex of meso and metatibiae.

\section{Material examined}

Neotype (by present designation)

BRAZIL • ô; "[illegible, probably "Adelaid"]" [handwritten label]; "Bowring. 63-47*" [white typewritten label]; "So named in Reiches Collection. C. W." [white typewritten label, C.W. indicating NHMUK entomology C.O. Waterhouse]; "Hoplognathus kirbyi McLeay" [handwritten by Waterhouse on reverse of previous label]; "NHMUK 010806029" [white typewritten label with QR code] (Fig. 2e); "NEOTYPUS Oplognathus kirbii MacLeay, 1819 Carvalho, Seidel \& Grossi des." [red typewritten label]; NHMUK.

Additional material (21 specimens)

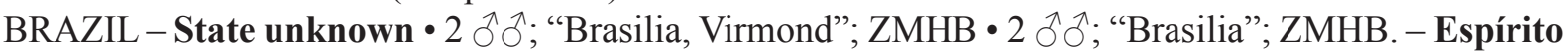
Santo • 1 đ̊; Palmital; 15 Dec. 1908; F.J. Zikán leg.; CEIOC. - Rio de Janeiro • 1 đ̊; Engenheiro Paulo de Frontin, Instituto Zoobotânico Morro Azul; 28 Dec. 2002; F. Racca Filho leg.; CERPE $\bullet 2$ ठิ ô; NHMUK. - São Paulo・ 1 đ̃; "Bosque d.S.”; 30 Oct. 1926; F. Ohaus leg.; ZMHB • 1 ô; Saude; 15 Oct.

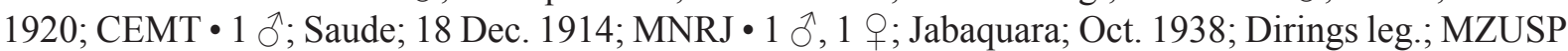
- 1 ; Jabaquara; Feb. [1]936; IBSP-IB • 1 \%; Jabaquara; Dec. [1]933; IBSP-IB • 1 \%; Jabaquara; 2 Dec. [19]39; MNRJ • 1 क; Mogy das Cruzes; H. Rüderw leg.; ZMHB • 1 §; Parque do Estado de Paulo;

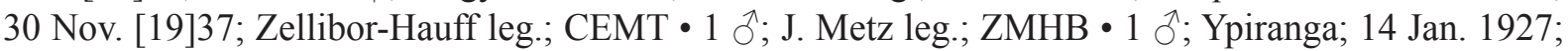
F. Ohaus leg.; NHMUK. - Minas Gerais • 1 ô; Manhumi[ri]n; 15 Dec. [19]35; MNRJ.

\section{Description}

\section{Male}

SizE. Total length 19.15-22 mm; width across prothorax: 8.0-10.6 mm.

CoLour. General aspect golden yellow with green reflection, ventral surface metallic green; head and legs reddish brown to metallic green; pygidium greenish brown with green reflections (Fig. 1a).

HEAD. Clypeus subquadrangular, surface rugose; apex weakly trilobate, lateral lobes almost straight, central lobe rounded; margins bowed inward, slightly widening from base to apex; ventral surface moderately punctate (Fig. 3a). Frontoclypeal suture distinct, straight. Length of clypeus about $1.5 \times$ longer than frons. Frons distinctly punctate, surface glabrous. Last maxillary palpomere cylindrical (Fig. 4c). Mentum $1.2 \times$ longer than wide, anterior margin sinuous, posterior angles distinctly acute 


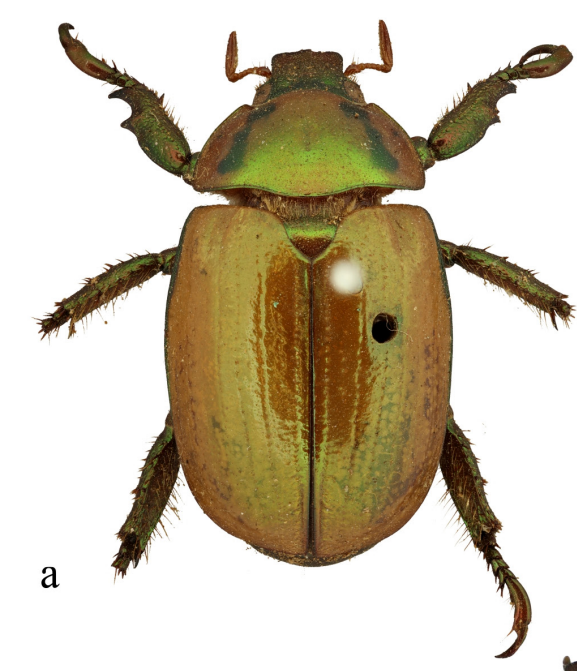

$\mathrm{b}$
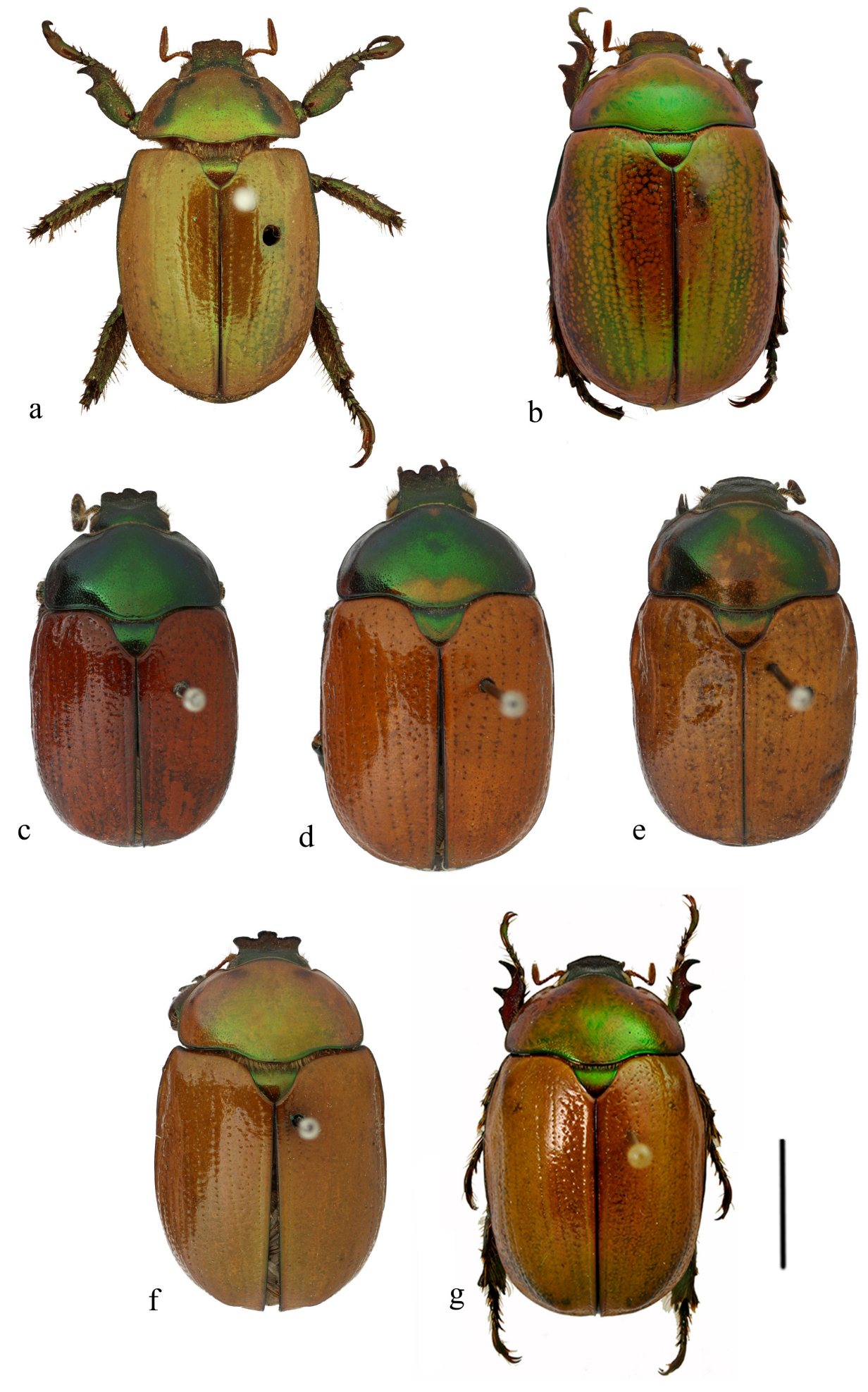

Fig. 1. a-b. Oplognathus kirbii MacLeay, 1819. a. Neotype, đ (NHMUK). b. Female specimen (MZUSP). c. O. helmenreichi Ohaus, 1905, holotype, $\widehat{\partial}$ (ZMHB). d-e. O. helmenreichi var. maculicollis Ohaus, 1914. d. Syntype, $\widehat{\partial}$ (ZMHB). e. Syntype, $\uparrow$ (ZMHB). f-g. O. bahianus Ohaus, 1912. f. Syntype, $\hat{\delta}(\mathrm{ZMHB})$. g. Female specimen (EPGC). Scale bar $=5 \mathrm{~mm}$. 
(Fig. 4d); surface densely punctate, and sparsely setose, setae as long as length of last labial palpomere. Antennal club $1.3 \times$ longer than antennomeres $2-7$ combined.

Thorax. Pronotum with surface moderately punctate; anterolateral maculae as spots with up to three setae on maculae; anterior angles acute (Fig. 3a). Propleuron slightly concave, surface moderately setose. Scutellar plate densely and uniformly punctate. Elytra with obsolete striae; first interstriae with punctuation sparse to moderate; each epipleuron slightly dilated on anterior half of elytron. Epipleuron concave with surface sparsely punctate, and sparsely setose. Mesoventral process long with apex acute, never reaching procoxal base, moderately setose and moderately punctate (Fig. 8a, d). Metasternum densely punctate, and densely setose. Procoxa densely punctate and sparsely setose. Profemur moderately punctate, moderately setose on lateral carina, setae shorter than wide on profemur. Mesofemur flattened, surface moderately punctate, and moderately setose. Metafemur flattened, broader, with surface sparsely punctate, and sparsely setose posteriorly. Protibia densely setose laterally, sparsely setose at disc, with setae shorter than wide on protibia, apex with 9-14 setae; densely punctate, big punctures; tibial spur as long as protarsomere I. Mesotibia sparsely setose dorsally, setae shorter than wide on mesotibia, and densely setose ventrally, with setae longer than wide on mesotibia; densely punctate; with two carinae, one proximal formed by 3-5 spinules, and one distal formed by 5-7; apex truncate with 9-11 apical spinules. Metatibia similar to mesotibia, but with 16-19 apical spinules; proximal carina with 2-4 spinules; and distal carina with 6-8 spinules.

ABDOMEN. Pygidium transverse, subtrapezoidal, surface sparsely setose, setae fine, and medial-posteriorly disposed. Ventrites in general aspect convex, ventrites II-IV with a slight central concavity, and with sparse setae and sparse punctures posteriorly. Parameres transverse, broader, apex V-shaped, left side slightly shorter, base rounded; left side of parameres expanded in lateral view, expansion parabolic, and with two apical lobes, almost with same length; right side of parameres sinuous, with two apical lobes, outer lobe shorter; paramere base almost straight, with discrete sinuosity (Figs 5a-c, 7a-d).

Female (Fig. 1b)

Similar to males, differing in the following aspects: Total length: $21.2-22.0 \mathrm{~mm}$; width across prothorax: 10.1-10.4 mm. Clypeus rounded, frontoclypeal suture weakly sinuous; elytral epipleuron more strongly dilated; protibia thinner; mesotibia varying from 9-10 spinules, and metatibia varying from 18-23; protarsomere I longer in length, protarsomere V not dilated; tarsal claws similar in length and width.

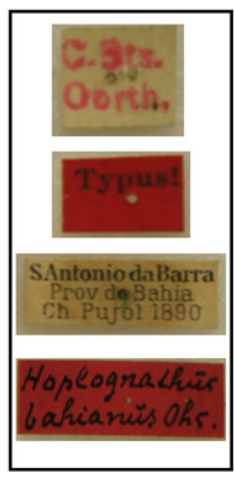

a

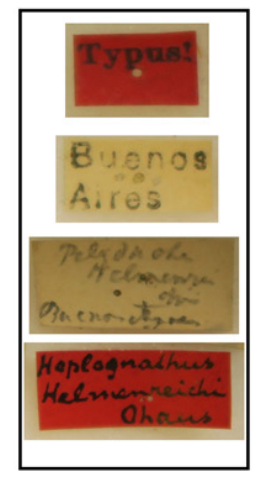

b

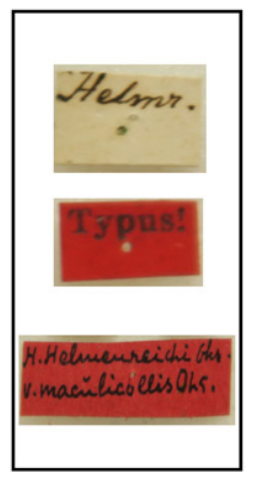

c

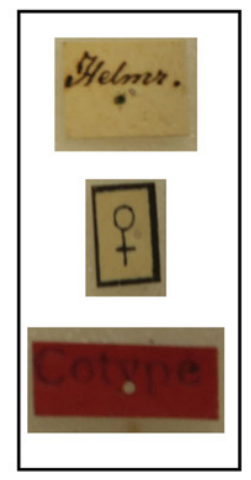

d

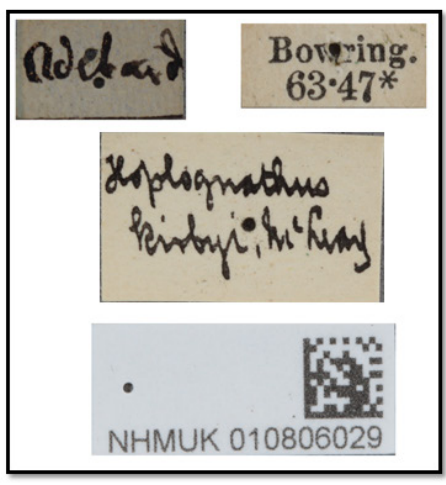

e

Fig. 2. Labels. a. Oplognathus bahianus Ohaus, 1912, syntype, ô. b. O. helmenreichi Ohaus, 1905, holotype, $\widehat{\jmath}$. c-d. O. helmenreichi var. maculicollis Ohaus, 1914. c. Syntype ${ }^{\dagger}$. d. Syntype + . e. O. kirbii MacLeay, 1819, neotype, ô. 


\section{Type locality}

Brazil.

\section{Remarks}

The holotype of Oplognathus kirbii MacLeay, 1819 is currently considered lost, and could not be traced in any of the likely collections. A neotype is designated to stabilize the nomenclature. We selected the oldest historical specimen, one that was received by NHMUK with Bowring's collection in 1863 [accession number 47]. The neotype fits the drawing of Guérin-Meneville (1844), the earliest illustration of the species (25 years after the description) which helps ensure that we selected the correct taxon. MacLeay (1819) provided only "Brazil" as the type locality. Since $O$. kirbii is a Brazilian endemic it is not a problem that the collecting data of the neotype are illegible.

\section{Distribution}

Brazil. Espírito Santo: Palmital; Minas Gerais: Manhumirin; Paraná; Rio de Janeiro: Engenheiro Paulo de Frontin; São Paulo: São Paulo (Fig. 9).

Oplognathus kirbii can be found in the mountainous regions of the states of Rio de Janeiro, São Paulo, Espírito Santo and Minas Gerais, besides being recorded in literature for the state of Paraná (specimens from Paraná have not been confirmed here), inhabiting humid areas of the Atlantic Forest, unlike the other species of the genus, found in areas of Mata Seca in the north of Minas Gerais.

Oplognathus helmenreichi Ohaus, 1905

Figs 1c-e, 2b-d, 3c-d, 4i-m, 6, 7e-h, 8c, f, 9

Hoplognathus helmenreichi Ohaus, 1905: 322.

Hoplognathus helmenreichi - Ohaus 1914a: 301 (species description); 1918: 12 (catalogue). Blackwelder 1944: 235 (catalogue).

Hoplognathus helmreicheni - Ohaus 1914a: 302 (species description); 1918: 12 (catalogue); 1934: 42 (catalogue). - Blackwelder 1944: 235 (catalogue).

Oplognathus helmreicheni-Machatschke 1972: 5 (catalogue). — Krajcik 2007: 90 (catalogue).

Oplognathus helmenreichi - Machatschke 1972: 5 (catalogue).

Hoplognathus helmreicheni var. maculicollis - Ohaus 1914a: 302 (description, infrasubspecific name, unavailable).

\section{Diagnosis}

Elytra reddish brown to orange yellow; male with clypeus moderately trilobate, lobes distinctly rounded, sides parallel (Figs 1c-e, 3c-d); antennal club 1.8× longer than antennomeres 2-7 combined (Fig. 3cd); females with club length $1.5 \times$ longer than antennomeres $2-7$ combined; last maxillary palpomere cylindrical in both sexes (Fig. 41); mentum longer than wide, anterior margin slightly sinuous, posterior angles rounded (Fig. 4m). Elytral striae distinctly marked; elytral epipleuron of female slightly dilated; mesoventral process long, apex rounded, never reaching anterior coxae (Fig. 8c, f); apex of the mesotibia with 7-13 spinules; apex of metatibia with 14-22 spinules in both sexes.

Material examined (Figs 1c, 2b)

\section{Holotype}

ARGENTINE - O', holotype of Oplognathus helmenreichi Ohaus, 1905; "Buenos Aires" [white typewritten label]; "Pelidnota Helmenreichi Buenos Aires" [white handwritten label]; "Typus!" [red typewritten label]; "Hoplognathus Helmenreichi Ohaus" [red handwritten label]; ZMHB. 
Syntypes

COUNTRY UNKNOWN • $\widehat{O}$, syntype of Oplognathus helmenreichi var. maculicollis Ohaus, 1914 (Figs 1d, 2c) • "Typus!" [red typewritten label]; "Helmr." [white handwritten label]; "H. Helmenreichi Ohs. v. maculicollis Ohs." [red handwritten label]; "SYNTYPE Hoplognathus helmenreicheni var. maculicollis Ohaus, 1914 labelled by MFNB 2017" [red typed label]; ZMHB • ${ }^{+}$, syntype of Oplognathus helmenreichi var. maculicollis Ohaus, 1914 (Figs 1e, 2d); "O+" [white typewritten label with black border]; "Cotype" [red typewritten label]; "Helmr." [white handwritten label]; "SYNTYPE Hoplognathus helmenreicheni var. maculicollis Ohaus, 1914 labelled by MFNB 2017” [red typed label]; ZMHB.

Additional material (six specimens)

COUNTRY UNKNOWN • "Ohaus determin. 1913 Hopl. Helmenreichi v. maculicollis Ohs. Cotype $\odot " ;$ NHMW.

BRAZIL - Minas Gerais • $4 \hat{\jmath} \widehat{\jmath}$; Leme do Prado, Estação Ecológica de Acauã; 23 Dec. 2003; M.F. Vasconcelos leg.; UFMG-ICO. - Paraná • 1 Ȯ; Curitiba; 3 Aug. 2010; Oliveira leg.; CERPE.

\section{Redescription}

Male holotype (Figs 1c, 3c, 4i-m, 6a-c, 7e-f)

SizE. Total length: $17.6 \mathrm{~mm}$; width across prothorax: $9.1 \mathrm{~mm}$.

CoLour. General aspect metallic dark green and reddish brown; head, pronotum, legs and venter metallic green, elytra reddish brown.

Head. Clypeus with surface rugose, densely punctate, larges punctures, gradually coalescent from disc to margins; apex trilobate, lobes rounded, sides parallels with the slightly converging apex. Frontoclypeal suture obsolete, sinuous, forming an angle on disc. Clypeus and frons subequal in length. Frons subquadrangular, moderately punctate, more densely posteriorly, with medium to large punctures, coalescent in the margins (Fig. 3c). Maxillary palpi with last palpomere cylindrical, sensorial area oval, occupying two thirds of dorsal area (Fig. 41). Mentum near $1.2 \times$ longer than wide, anterior margin weakly sinuous, almost straight, posterior angles rounded (Fig. $4 \mathrm{~m}$ ); surface sparsely punctate with scattered setae, punctures large. Antennal club $1.8 \times$ longer than antennomeres $2-7$ combined.

Thorax. Pronotum with surface moderate to densely punctate, increasing density towards sides; anterior angles acute; sides slightly truncate (Fig. 3c). Propleuron slightly concave, surface rugose, and moderately setose. Scutellar plate moderately punctate, punctures bigger on disc. Elytral striae distinctly marked; first interstriae with puncture thin, dense. Epipleuron flattened, sparsely setose, minute setae. Mesoventral process long with rounded apex, never reaching procoxal base (Fig. 8c, f); surface punctate and densely setose. Metasternum densely punctate and densely setose. Procoxa densely punctate and sparsely setose. Profemur sparsely punctate and sparsely setose. Mesofemur moderately punctate and densely setose. Metafemur flattened, broad, sparsely punctate, and with sparse posterior setae. Protibia with surface densely punctate, bigger punctures, C-shaped punctures on disc; apex with 10 distinct setae. Mesotibia with two transverse carinae: proximal carina marked by four spinules, distal carina marked by five spinules, surface moderately punctate and sparsely setose, short setae; apex with 11 spinules. Metatibia similar to mesotibia, but more robust and with 19 apical spinules.

AbDomen. Pygidium subtrapezoidal, apex slightly rounded, surface rugose, minute setae sparsely disposed on margins. Ventrites with surface sparsely setose, fine and short setae. Parameres similar in length, irregularly V-shaped bifurcated, bifurcation base rounded; apical lobes well defined, left lobe smaller than right lobe; left lateral expanded in lateral view, parabolic expansion; right expansion obsolete (Figs 6a-c). 


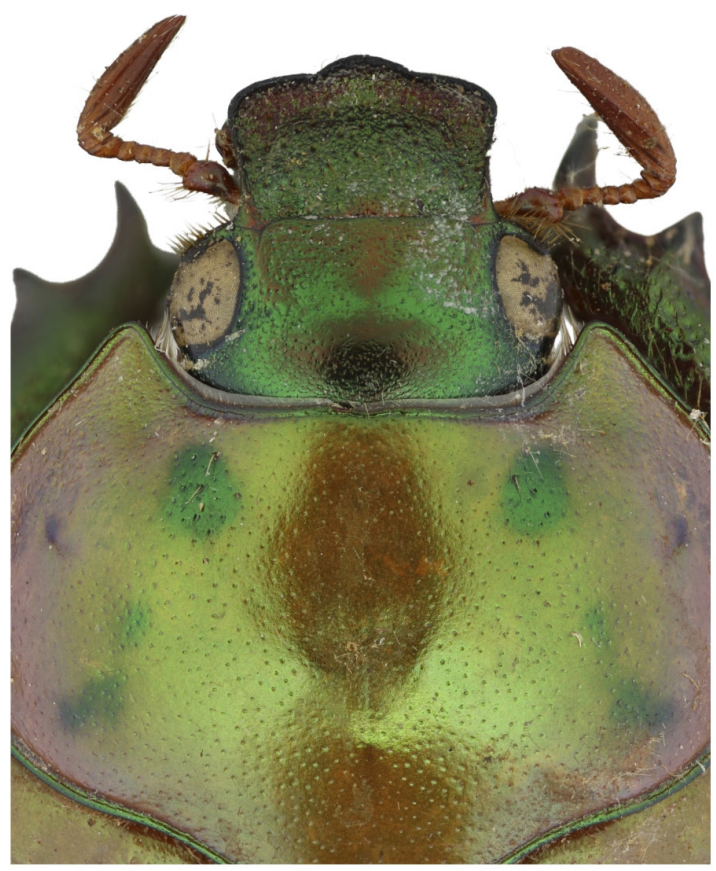

$\mathrm{a}$

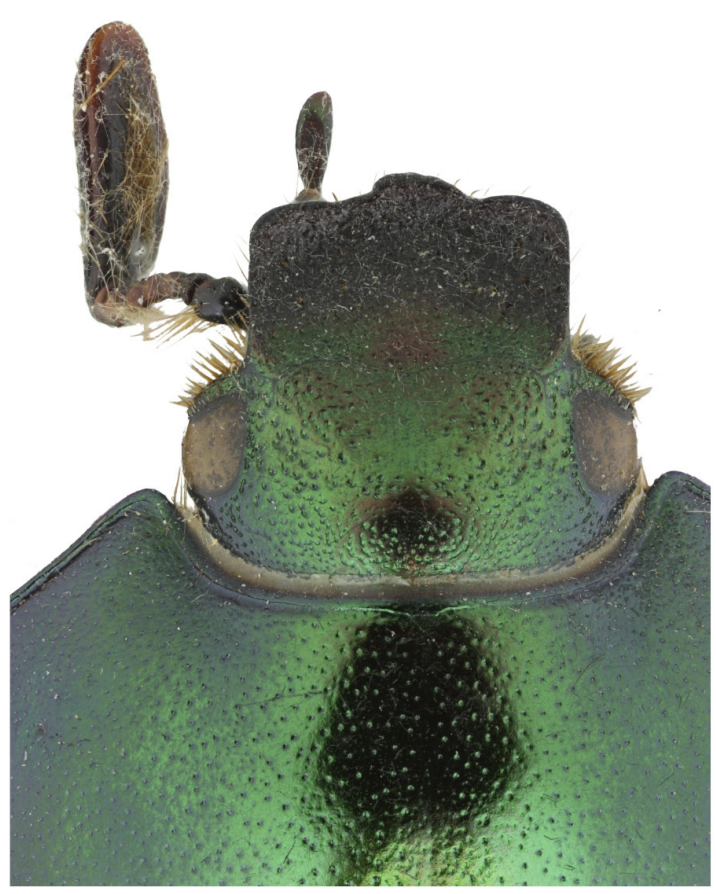

c

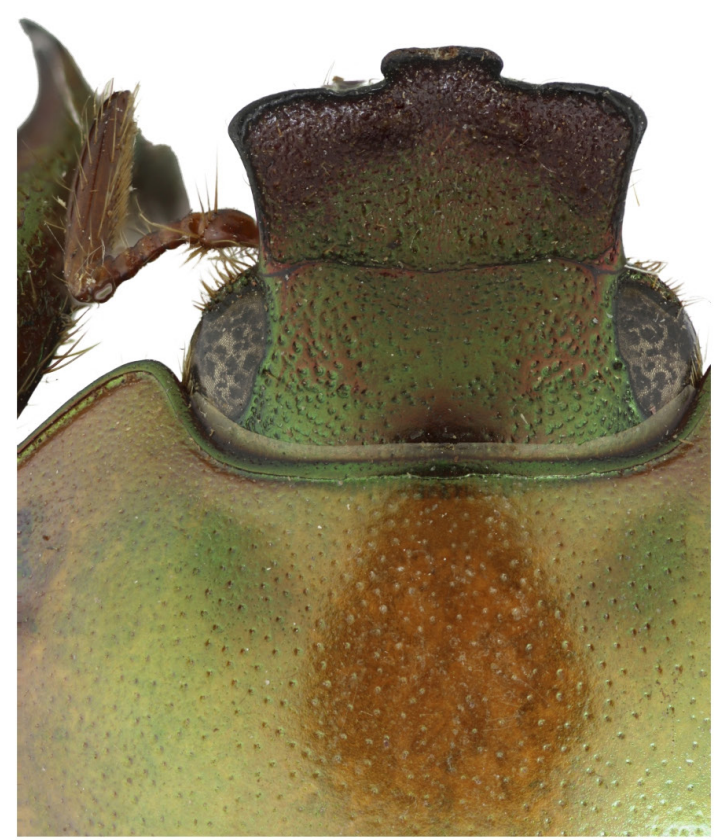

b

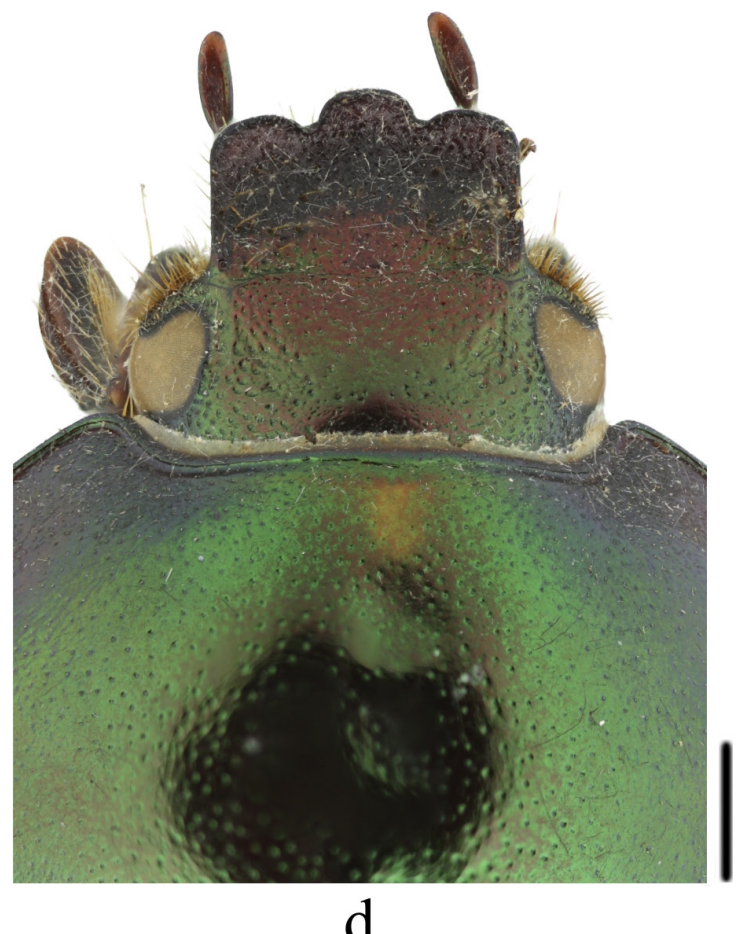

Fig. 3. Head and pronotum details. a. Oplognathus kirbii MacLeay, 1819, male specimen (ZMHB). b. O. bahianus Ohaus, 1912, syntype, $\sigma^{\Uparrow}$ (ZMHB). c. O. helmenreichi Ohaus, 1905, holotype, ô (ZMHB). d. O. helmenreichi var. maculicollis Ohaus, 1914, syntype, đ̊ (ZMHB). Scale bar $=1 \mathrm{~mm}$. 


\section{Male variation}

Size: total length: 17.2-19.0 mm; width across prothorax: 7.5-9.1 mm. General aspect orange-brown; head, pronotum and scutellar plate may have yellowish maculae (Fig. 1d-e). Suture frontoclypeal vary in the degree of sinuosity. Pronotum can be more or less truncate at sides. Surface of mesofemur varies from moderately to densely punctate. Mesotibia with proximal and distal carina marked by 4-7 spinules; apex truncate with 7-13 spinules. Metatibia with 14-22 spinules in the apex, distal carina with 5-11 spinules, and proximal carina with 5-8. Parameres vary from parabolic curvature of the aedeagus to the truncate curvature, as well as, in the degree and shape of lateral expansion, it can be longer and more parabolic (Figs 6d-f, 7e-h).

Female (Fig. 1e)

Similar to males in general aspects, differentiating in the following aspects: pronotal maculae more elongate; clypeus rounded; frontoclypeal suture distinct, with central curvature; antennal club $0.7 \times$ smaller than in males, $1.5 \times$ longer than antennomeres $2-7$ combined. Pronotum with parallel sides and
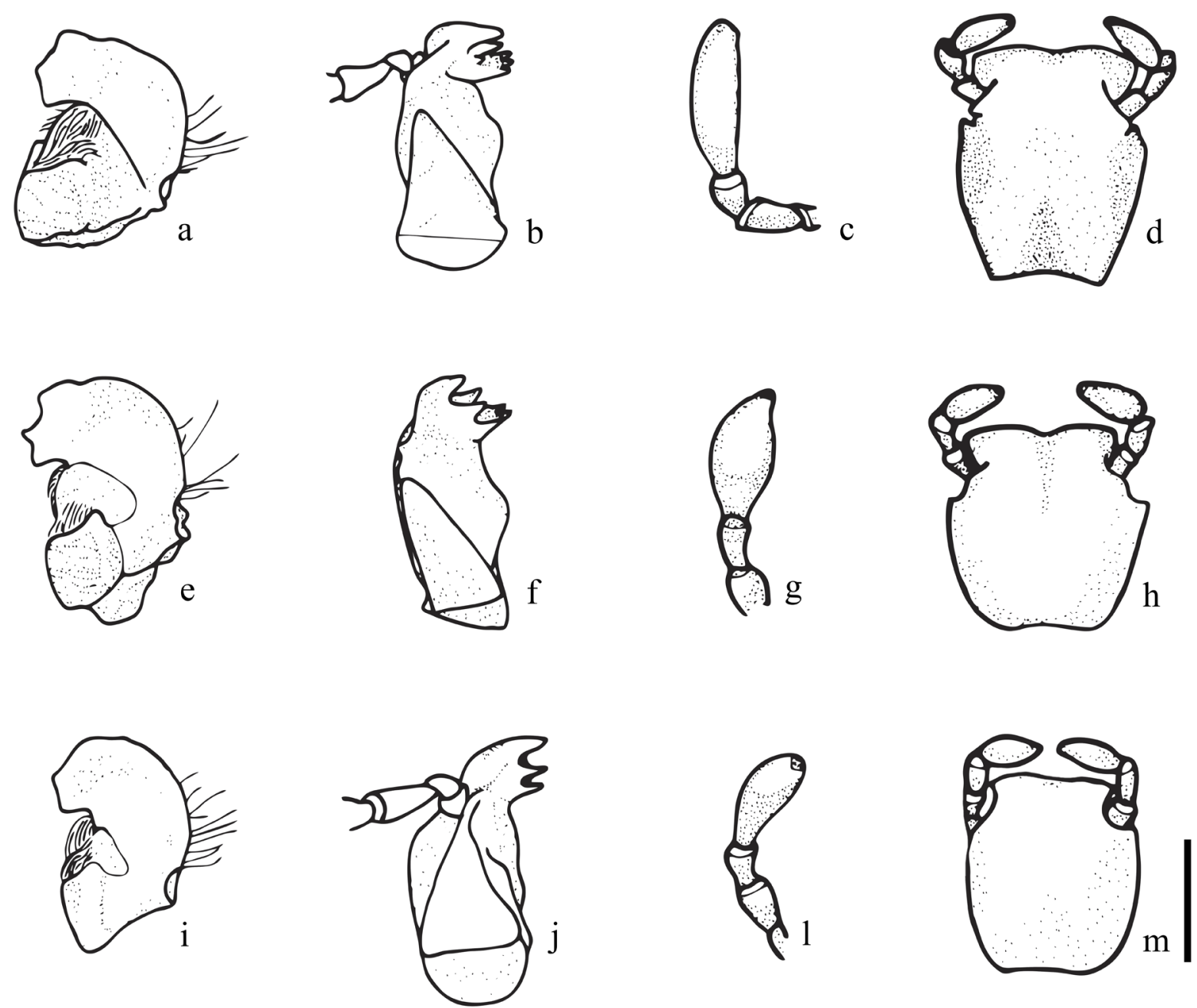

Fig. 4. Mouthparts. a-d. Oplognathus kirbii MacLeay, 1819 (ZMHB). e-h. O. bahianus Ohaus, 1912 (ZMHB). i-m. O. helmenreichi Ohaus, 1905 (ZMHB). a, e, i. Right mandible. b, f, j. Right maxilla. $\mathbf{c}, \mathbf{g}, \mathbf{l}$. Detail of the last maxillary palpomere. $\mathbf{d}, \mathbf{h}, \mathbf{m}$. Mentum. Scale bar $=1 \mathrm{~mm}$. 
anterior angles more rounded. Elytral epipleuron slightly rounded, distinct depression above epipleuron. Protarsomere I as long as protarsomeres II-IV combined.

\section{Type locality}

Oplognathus helmenreichi was originally described from Buenos Aires (Argentina) (Ohaus 1905), and this locality was later contested by the author (Ohaus 1914a) while describing the variety, O. helmenreichi var. macullicolis. This species can actually be found in the north and northeast of Minas Gerais state in

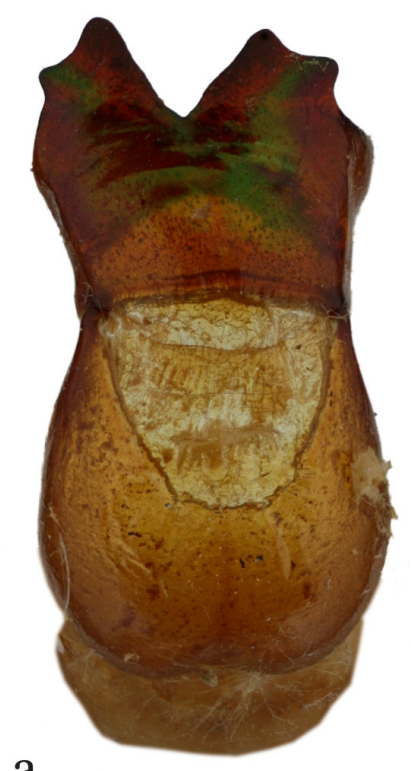

a

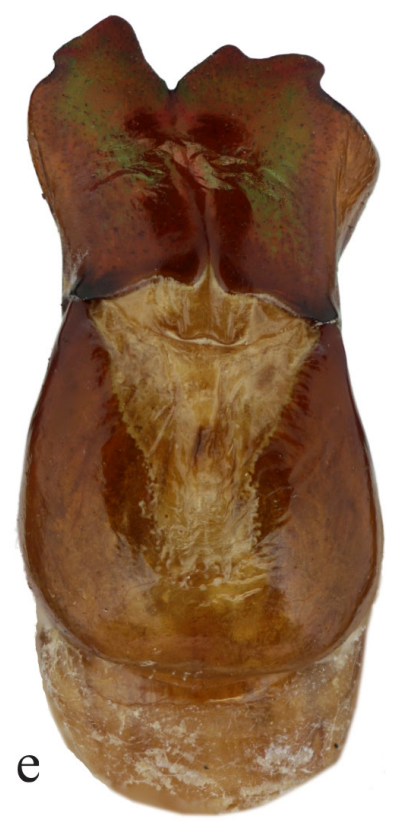

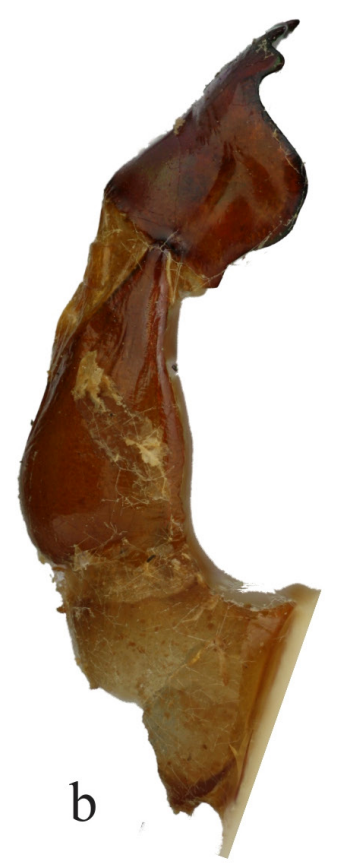
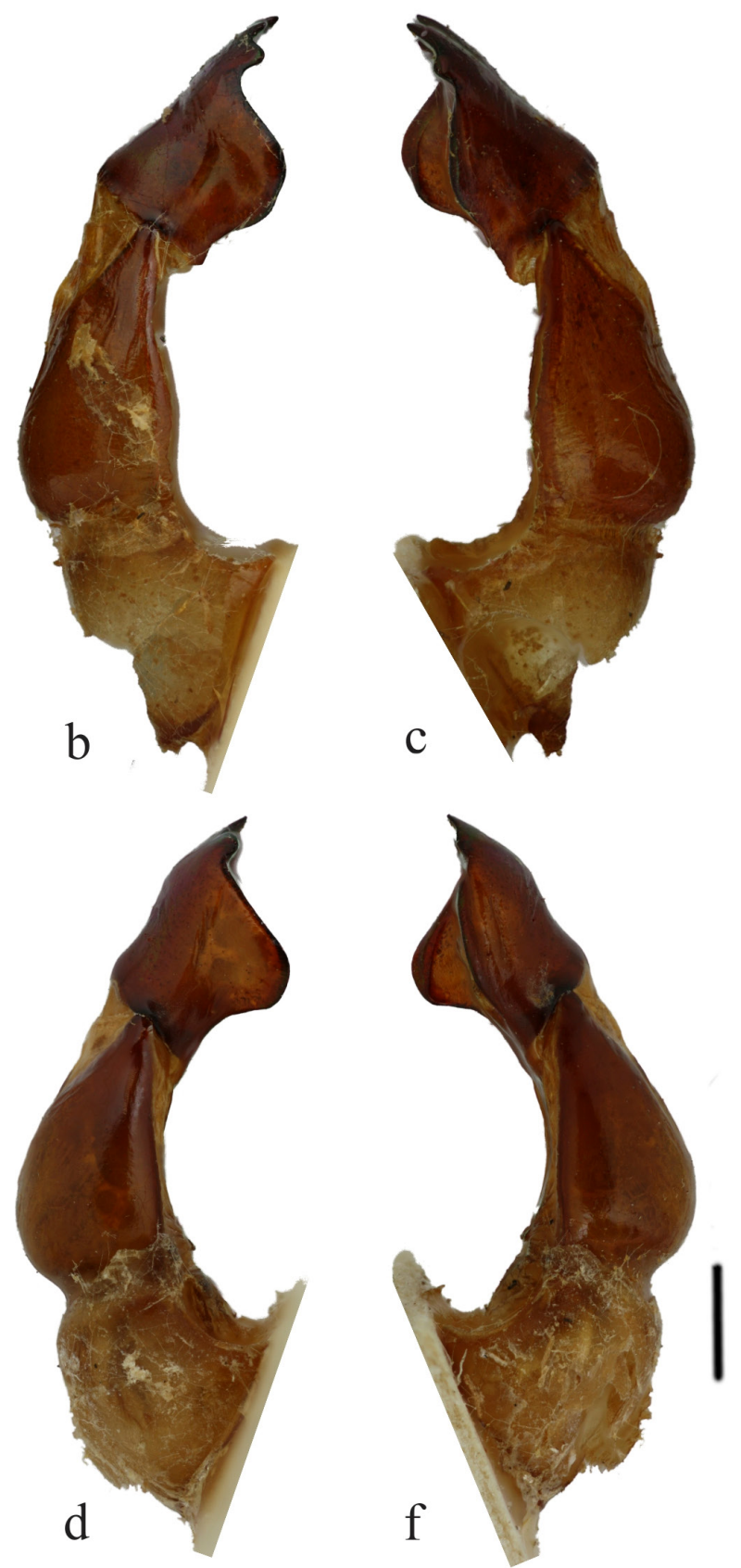

Fig. 5. Aedeagus in dorsal (a, e) y lateral view (b-c, d, f). a-c. Oplognathus kirbii MacLeay, 1819 (ZMHB). d-f. Oplognathus bahianus Ohaus, 1912, syntype, ô (ZMHB). Scale bar $=1 \mathrm{~mm}$. 
the Jequitinhonha River Valley (Ohaus 1914a). Accordingly, after the examination of three more males from the same region, we agree with Ohaus (1914a) and disregard the occurrence of O. helmenreichi in Argentina.

\section{Remarks}

We consider the type of Oplognathus helmenreichi a holotype since Ohaus (1905) mentions only a single specimen. For Oplognathus helmreicheni var. maculicollis Ohaus (1914a) had multiple specimens available. ICZN (1999, Article 45.6.1.) states that a name "is infrasubspecific if its author expressly gave it infrasubspecific rank, or if the content of the work unambiguously reveals that the name was proposed for an infrasubspecific entity". Furthermore, the Article 45.6.4. (ICZN 1999) clarifies that a name "is subspecific if first published before 1961 and its author expressly used one of the terms "variety" or "form" (including use of the terms "var.", "forma", "v." and "f."), unless its author also expressly gave it infrasubspecific rank, or the content of the work unambiguously reveals that the name was proposed for an infrasubspecific entity, in which case it is infrasubspecific". In the time Ohaus described Oplognathus helmenreichi var. maculicollis he already clearly separated between species, subspecies and varieties as an article from the same year (see Ohaus 1914b) shows where he described new taxa on the species, subspecies and infrasubspecific levels. Therefore, Oplognathus helmenreichi var. maculicollis is an unavailable name. Although the pair of syntypes of $O$. helmenreichi var. maculicollis examined have some distinct characteristics of the holotype - such as yellowish colour, smaller size, less dense punctures and the male genitalia almost parallel sided, the other specimens examined show many similarities both with the syntypes and with the holotype. The variation of these characteristics was also observed within the other species of the genus. Despite these variations, mouthpart characters (like mentum shape, maxillary palpus shape) and mesoventral process remained constant in the eight specimens examined. Thus, Oplognathus helmenreichi var. maculicollis does not present a unique combination of character states that justify validating it to species or subspecies status.

\section{Distribution}

Brazil: Minas Gerais: Grão Mogol, Leme do Prado. Paraná: Curitiba? (Fig. 9).

No other specimen of $O$. helmenreichi was subsequently collected in Buenos Aires, or anywhere else in Argentina (Ohaus 1914a). One part of the material of O. helmenreichi var. maculicollis was labelled "Helm., Brasilia, XXII, 1853" and the other part "Serra do Grão Mogor, 1846" [Municipality of Grão Mogol, Minas Gerais]. Ohaus (1914a) then made it clear that the most probable locality of this species would be the north of Minas Gerais State (Grão Mogol) and not Buenos Aires, corresponding to the known distribution of the genus. Thus, we agree with Ohaus (1914a) and disregard Buenos Aires as a locality for this species, as well as for the genus Oplognathus. One male of the examined material is labelled as being from Curitiba, Paraná, South of Brazil, but the origin is doubtful, since this single specimen was found in a didactic collection of the Federal University of Paraná.

Oplognathus bahianus Ohaus, 1912

Figs 1f-g, 2a, 3b, 4e-h, 5d-f, 7i-m, 8b, e, 9

Hoplognathus bahianus Ohaus, 1912: 650.

Hoplognathus bahianus - Ohaus 1918: 12 (catalogue); 1934: 42 (catalogue). — Blackwelder 1944: 235 (catalogue).

Oplognathus bahianus - Machatschke 1972: 5 (catalogue). — Krajcik 2007: 90 (catalogue). 


\section{Diagnosis}

Male with truncate, strongly, trilobate clypeus, rounded in females; clypeus with divergent sides (Fig. 3b). Antennal club of the males $1.5 \times$ longer than antennomeres 2-7 combined. Male with last maxillary palpomere fusiform (Fig. 4g), cylindrical in females. Mentum broad, as long as wide, anterior margin notched, posterior angles rounded (Fig. 4h). Elytral striae distinctly marked. Mesoventral process short and slightly flat, with apex slightly rounded (Fig. 8b, e). Apex of the mesotibia with 9-12 spinules and apex of the metatibia with 18-20 spinules, females with 24-27 spinules at the apex of the metatibia.
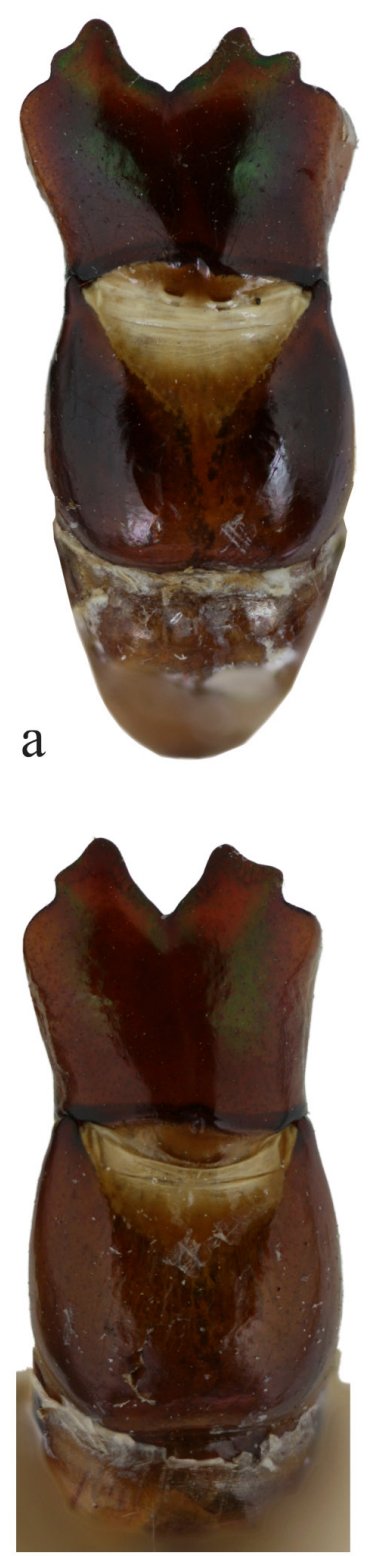

$\mathrm{e}$

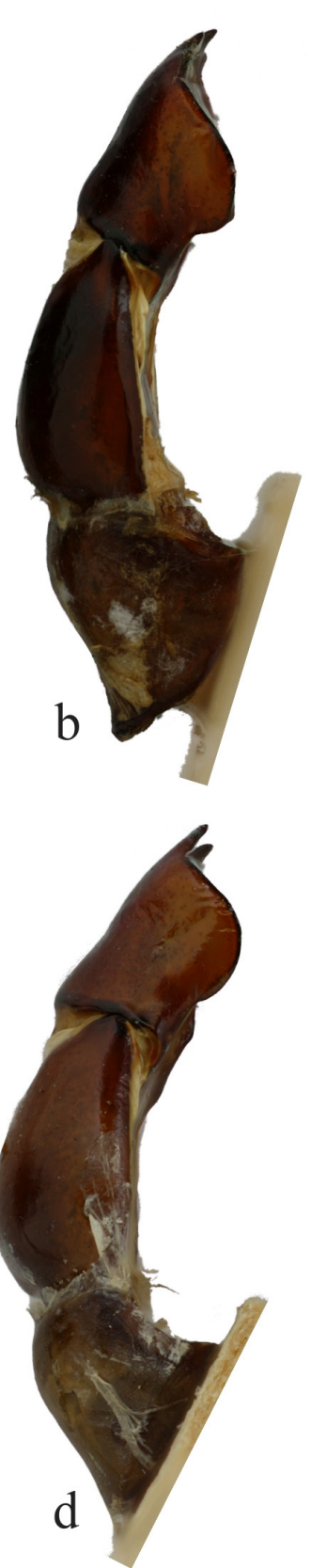

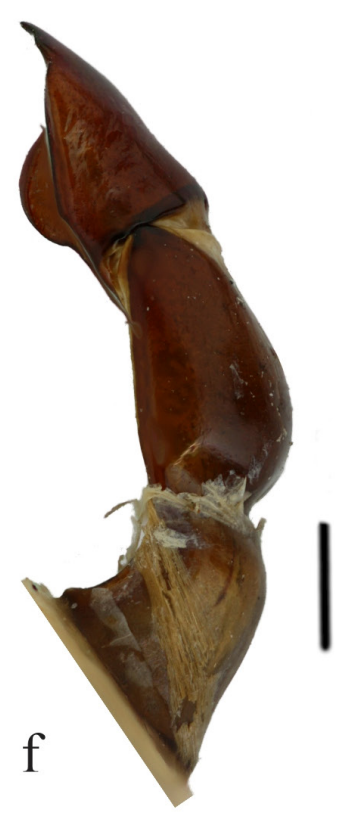

Fig. 6. Aedeagus in dorsal (a, e) and lateral view (b-c, d-f). a-c. Oplognathus helmenreichi Ohaus, 1905, holotype, ô (ZMHB). d-f. O. helmenreichi var. maculicollis Ohaus, 1914, syntype, ठิ (ZMHB). Scale bar $=1 \mathrm{~mm}$. 


\section{Material examined}

Syntype

BRAZIL • O’, syntype of Oplognathus bahianus Ohaus, 1912 (Figs 1f, 2a); "Typus!" [red typewritten label]; "C. Bts. Obrth." [white handwritten label]; "SAntonio da Barra Prov. de Bahia Ch. Pujol 1890" [white typewritten label]; "Hoplognathus bahianus Ohs." [red handwritten label]; ZMHB.

Additional material (six specimens)

BRAZIL - Minas Gerais • 1 đ̆; Berizal; 15 Dec. 2007; Grossi, Rafael \& Parizotto leg.; CERPE • 1 đ; Berizal; Dec. 2001; P. Grossi leg.; CERPE • 3 đô, 1 क् ; Águas Vermelhas; Nov. 1991; E. Grossi leg.; EPGC.

\section{Redescription}

Syntype male (Figs 1f, 3b, 4e-f, 5d-f, 8b, e)

Size. Total length: $20.8 \mathrm{~mm}$; width across prothorax: $10.5 \mathrm{~mm}$.

CoLour. General aspect with dorsal surface yellow gold and ventral surface metallic green; head, legs, and pygidium from cooper to reddish brown with metallic green reflections.

HeAd (Fig. 3b). Clypeus subquadrangular, surface rugose, sparsely setose; apex strongly trilobate, truncate, margins bowed inward, sides clearly divergent; ventral surface moderately punctate and moderately setose. Frontoclypeal suture straight. Clypeus $1.3 \times$ longer than frons. Frons densely punctate, punctures coalescent laterally. Last maxillary palpomere fusiform, distinctly flattened (Fig. 4g); sensorial area oval, occupying two thirds of dorsal surface. Mentum $1.05 \times$ wider than long, subequal, anterior margin notched, posterior angles rounded (Fig. 4h); surface densely punctate, large punctures; surface sparsely setose, setae as long as the length of the labial palpus. Antennal club $1.5 \times$ longer than the antennomeres $2-7$ combined.

THORAX. Pronotum with surface moderately and uniformly punctate, thin punctures; surface glabrous; anterior angles rounded; maculae obsolete: two anterolateral maculae as cooper slight spots, and two lateral maculae heterogeneous (Fig. 3b). Propleuron concave, moderately setose and moderately punctate. Scutellar plate sparsely punctate. Elytra with 10 deeply marked striae, interstriae practically obsolete in general, first interstriae with dense puncture; epipleuron flattened, glabrous. Mesoventral process short with rounded apex, never reaching the apex of the mesocoxa, surface sparsely setose and densely punctate (Fig. 8b, e). Metasternum densely punctate, and densely setose. Procoxa rugose, surface sparsely setose. Profemur moderately setose. Mesofemur flattened, surface densely, and uniformly punctate; moderately setose. Metafemur flattened, broader, surface moderately, and uniformly punctate; moderately setose. Protibia moderately setose in the medial-inner portion, external portion sparsely setose; surface densely punctate, not uniform, big punctures, coalescent on the lateral portion; apex with a group of 11 setae. Mesotibia with surface sparsely setose dorsally, setae longer than wide mesotibia; surface densely setose ventrally; densely punctate, punctures big and small, not uniformly scattered; external surface with two carinae, proximal one short, marked by 3 spinules, and a distal complete, and oblique carina with 8 spinules; apex truncate with 13 spinules. Metatibia similar to mesotibia, but with 19 spinules on the apex.

Aвdomen. Pygidium subtrapezoidal, sparse setae disposed in the margins, disc glabrous. Ventrites with surface sparsely setose posteriorly in the ventrites II-IV, and restricted to the lateral of ventrite VI, moderate punctuation. Parameres transverse, apex emarginated like V-shaped, with the left side distinctly shorter and broader, the right side slightly sinuous, base notched, concave; right lateral paramere divergent, straight, toward the apex with a concavity; apex with an only oblique lobe, transverse and anterior face straight; left lateral paramere broadly rounded and expanded ventrally, long expansion, 

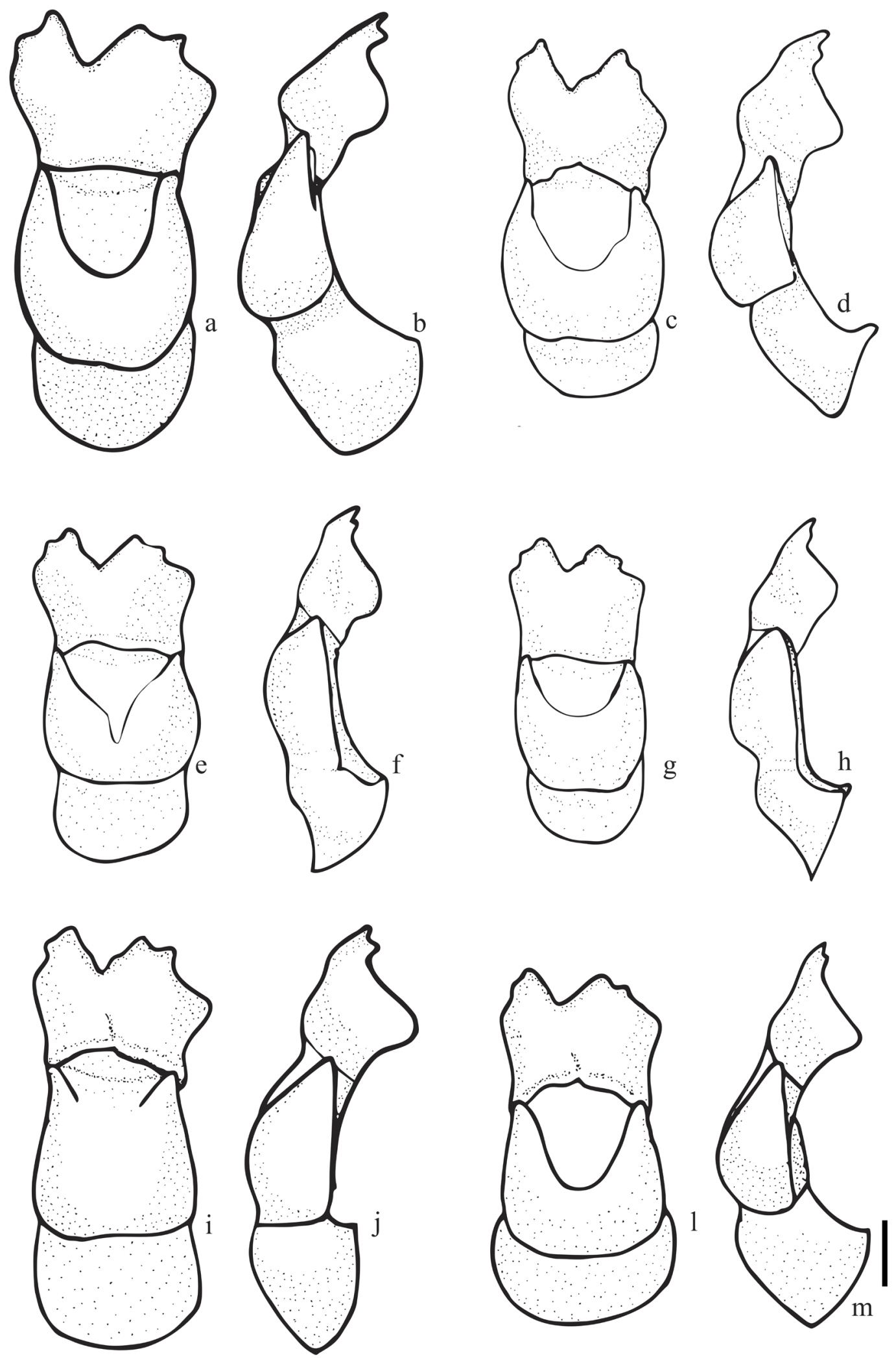

Fig. 7. Variation in male genitalia. a-d. Oplognathus kirbii MacLeay, 1819 (a-b: CEMT; c-d: ZMHB). e-h. O. helmenreichi Ohaus, 1905 (ZMHB). i-m. O. bahianus Ohaus, 1912 (CERPE). Scale bar = $1 \mathrm{~mm}$. 
apically of two lobes, external lobe projecting outwardly; base of parameres sinuous with median recess in V-shape (Fig. 5d-f).

\section{Male variation}

Size: total length: $20.0-20.8 \mathrm{~mm}$; width across prothorax: 10.0-10.5 mm. Frontoclypeal suture can be slightly sinuous. Mentum can have the anterior margin more or less curved, but all specimens show the notched type; mentum vary from 1.3-1.8 $\times$ longer than frons. Pronotal and elytral punctation are distinctly marked, but one specimen has them very smooth. Surface on the scutellar plate varies from sparsely to moderately punctate. Mesoventral process is predominantly short with a rounded apex, one specimen has it more acute. Apex of protibia vary from 9-12 setae. Proximal carina of mesotibia varies by $2-3$ spinules, and the distal carina varies by 5-9 spinules; apex truncate with $9-13$ spinules. Metatibia with 18-20 spinules in the apex, distal carina with 7-11 spinules, and proximal carina with 3-5 spinules. Parameres vary in the degree of lateral inclination, lobes of parameres may be more or less pronounced, the lateral projections vary in length (Fig. 7i-m).

Female (Fig. 1g)

Similar to the male, differing from it in the following aspects: body usually more truncate, globose, distinctly convex. Total length: $22.1 \mathrm{~mm}$, width across prothorax: $11.1 \mathrm{~mm}$. Head with rounded clypeus, convergent sides; antennal club $0.7 \times$ shorter than in male. Last maxillary palpomere cylindrical, sensorial area straighter. Pronotal maculae obsolete; elytral epipleuron broader; protibial spur distinctly thinner; tarsal claws similar, without differentiation, anterior tarsus shorter; apex of metatibia with 24-27 apical spinules. Sixth sternite subtriangular, and more densely punctate almost rugose.

\section{Type locality}

Brazil. Bahia: [Santo Antônio da Barra], currently the municipality of Condeúba (Fig. 9).
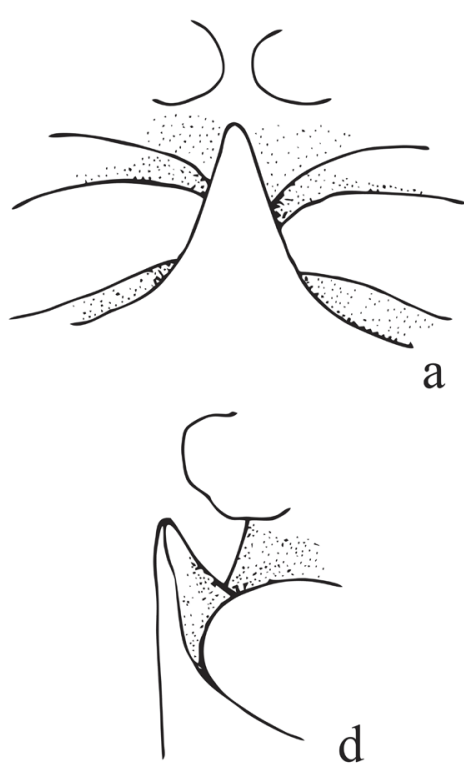
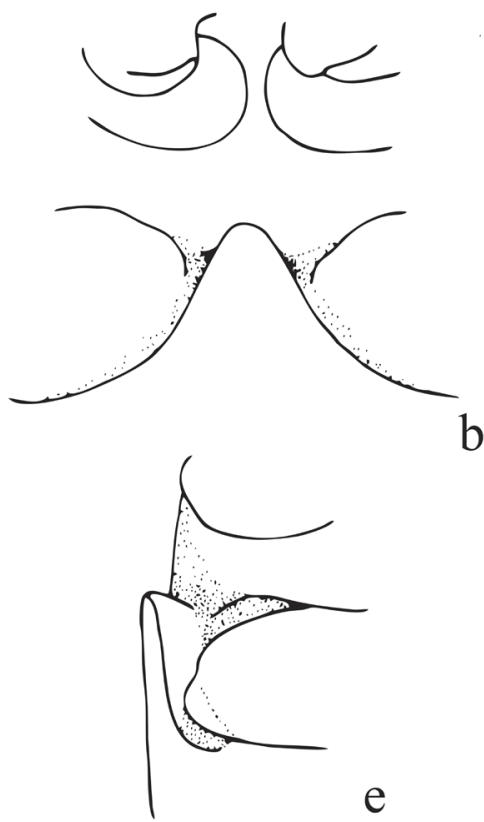
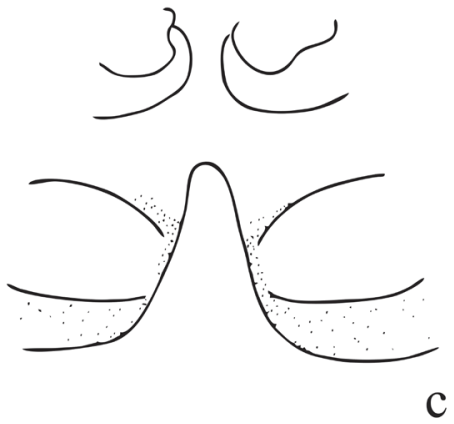

$\mathrm{C}$

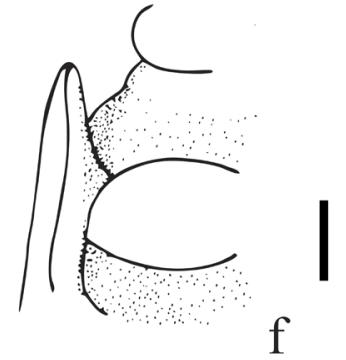

Fig. 8. Patterns of mesoventral process. a, d. Oplognathus kirbii MacLeay, 1819 (MZUSP). b, e. O. bahianus Ohaus, 1912 (ZMHB). c, f. O. helmenreichi Ohaus, 1905 (CERPE). Scale bar $=1 \mathrm{~mm}$. 


\section{Remarks}

Ohaus (1912) did not state the number of specimens and therefore, we consider the single type specimen as a syntype. Oplognathus bahianus is the most distinctive species of the genus, with the males presenting a strongly trilobed clypeus. However, this character does not fit the original diagnosis of the genus (based on the type species $O$. kirbii), where the clypeus was described with this character being less evident. Although being a secondary sexual character, the clypeus has been used as the main diagnostic character of the genus. After this study, despite concerning only one sex, the trilobed cypleus is the best character to distinguish $O$. bahianus. Another relevant character to distinguish this species is the mesoventral process, which is not salient and simply rounded, vs acute and salient in the two other species.

\section{Distribution}

Brazil. Bahia: Condeúba; Minas Gerais: Águas Vermelhas, Berizal (Fig. 9).

Oplognathus bahianus was described by Ohaus (1912) from Santo Antônio da Barra in Bahia. This locality received the denomination of Condeúba in 1889, and is located in the south-central region of the state in the Bahia Semiarid Region, near the north of Jequitinhonha Valley. This species has the northernmost distribution in Brazil, being also found in the north of Minas Gerais in the Jequitinhonha

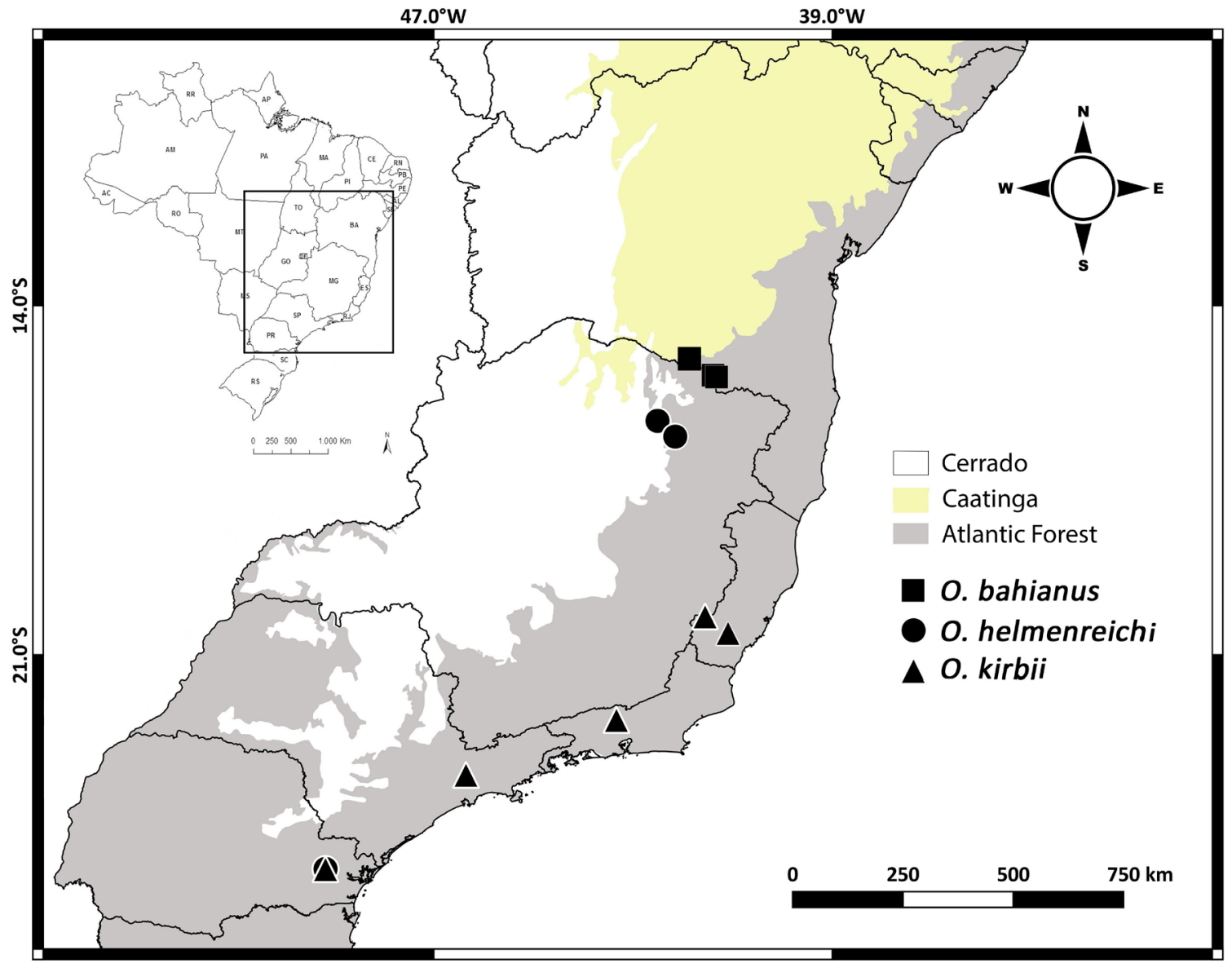

Fig. 9. Geographic distribution of Oplognathus MacLeay, 1819. 
River Valley Region, an ecotone characterized by transition from the Atlantic Forest, Cerrado and Caatinga, with a high degree of endemism.

\section{Discussion}

The genus Oplognathus is revised in this paper, with a redescription of the three species. The female of Oplognathus bahianus is described for the first time. The diagnostic characters of the genus are confirmed, distinguishing it from other Brazilian Areodina. Oplognathus is recovered as sister group of Areoda (Jameson 1990), sharing as common characters the presence of the mesoventral process and asymmetrical parameres, and the same geographic distribution (MacLeay 1819; Ratcliffe \& Jameson 1989). They differ in colour, size, clypeal shape (Ratcliffe \& Jameson 1989), and in paramere shape: in Areoda, the lateral processes are hooks, whereas they are lobes in Oplognathus. Oplognathus bears three distinct teeth on the mandibles; Areoda bears two teeth.

Characters such as the shape of the last labial palpomere, the depth of elytral striae, and the shape of parameres (commonly used as diagnostic characters in other genera within Scarabaeoidea Latreille, 1802, including Areoda) are not useful to separate species of Oplognathus, where these structures often vary within species. On the other hand, the characteristics of the mouthparts (such as mandible shape, the last maxillary palpomere, and mentum shape) are important for the species identification.

Despite being a genus with few species, many nomenclatural problems were encountered (detailed in the section 'nomenclatural history'), in addition to the lost type of Oplognathus kirbii. The type specimen of $O$. kirbii was not found in the MacLeay Museum (MMUS), nor in the Natural History Museum London (NHMUK), where the MacLeay collection is housed. Ratcliffe \& Jameson (1989) reported that George Masters, curator of the MacLeay Museum collection from 1872 to 1912, relabelled many specimens and destroyed the original labels. However, all the examined specimens identified as O. kirbii were conspecific, in addition to an illustration of Guérin-Méneville (1844: pl. 24 bis fig. 10). Therefore, we designate a neotype to stabilize the classification of the genus and species. This genus can be considered rare, due to the few specimens in collections. In most cases, the specimens are very old, with no precise data and there are almost no recent records. Oplognathus kirbii is the most present species in collections, quite possibly because the localities where it occurs were more sampled in the past.

\section{Acknowledgments}

We thank the Conselho Nacional de Desenvolvimento Científico e Tecnológico - CNPq for supporting the research with grants to TGC (132551/2016-0), and PCG (449366/2014-4). The images of the types from ZMHB were enabled through the SYNTHESYS project DE-TAF-6712 granted to Matthias Seidel. We also thank Prof. Dr ${ }^{\mathrm{a}}$ Paula Braga (UFRPE) with nomenclature decisions, as well as the curators of the collections EPGC, CEMT, MZUSP, IBSP-SP, MNRJ, ZMHB, NHMUK, NHMW, CEIOC, CMNC, UFMG ICO for the loan of the material, and Mr Robert Blackburn (MacLeay Museum) for his kindness in searching for the type specimen of $O$. kirbii.

\section{Conflicts of interest}

The authors declare no conflicts of interest.

\section{References}

Blackwelder R.E. 1944. Checklist of the Coleopterous insects of Mexico, Central America, the West Indies and South America. Part 2. Bulletin of the United States National Museum 185: 189-341. https://doi.org/10.5479/si.03629236.185.2 
Burmeister H. 1844. Handbuch der Entomologie, vol. 4, part 1. TCF Enslin, Berlin. https://doi.org/10.5962/bhl.title.8135

Carvalho T.G. \& Grossi P.C. 2018. Description of a second species of the genus Moronius Grossi \& Vazde-Mello, 2015 (Coleoptera: Scarabaeidae: Rutelinae: Rutelini). Zootaxa 4434: 369-372.

https://doi.org/10.11646/zootaxa.4434.2.7

Dejean P-F. 1837. Catalogue des Coléoptères de la collection de M. le Comte Dejean. Tome III. Chez Méquignon-Marvis Père et Fils, Paris. https://doi.org/10.5962/t.173109

Grossi P.C. \& Vaz-de-Mello F.Z. 2015. Moronius miguelangeli new genus and new species of Areodina from western Brazil (Melolonthidae, Rutelinae, Rutelini). Dugesiana 22: 221-226.

ICZN (International Commission on Zoological Nomenclature) 1999. Código Internacional de Nomenclatura Zoológica. $4^{a}$ Ed. Comisión Internacional de Nomenclatura Zoológica c/o The Natural History Museum, Londres. Available from http://iczn.org/the-code [accessed 8 May 2021].

Guérin-Méneville M.F.E. 1844. Iconographie du Règne Animal de G. Cuvier: ou, Représentation d'après nature de l'une des espèces les plus et souvent non encore figurées de chaque genre d'animaux. J.B. Balliére, Paris / London. https://doi.org/10.5962/bhl.title.10331

Jameson M.L. 1990. Revision, phylogeny and biogeography of the genera Parabyrsopolis Ohaus and Viridimicus, new genus (Coleoptera: Scarabaeidae: Rutelinae). The Coleopterists Bulletin 44: 377-422.

Jameson M.L. 1997. Phylogenetic analysis of the subtribe Rutelina and revision of the Rutela generic groups (Coleoptera: Scarabaeidae: Rutelinae: Rutelini). $\mathrm{PhD}$ thesis, University of Kansas, Kansas.

Krajcik M. 2007. Anima. X. Rutelinae of the world. Checklist of Scarabaeoidea of the world. 2. Rutelinae (Coleoptera: Scarabaeidae: Rutelinae). Plzen, Czech Republic.

Lacordaire M.T. 1856. Histoire naturelle des Insectes. Genera des Coléoptères ou exposé méthodique et critique de tous les genres proposé jusqu'ici dans cet ordre d'insectes, tome III. Librairie Encyclopédique de Roret, Paris. https://doi.org/10.5962/bhl.title.8864

Laporte F. 1840. Histoire naturelle des Insectes Coléoptères, tome deuxième. Duménil Editeur, Paris.

Latreille M. 1829. Le Règne Animal distribué d'après son organisation, pour servir de base à l'histoire naturelle des animaux et d'introduction à l'anatomie comparée, tome IV. Chez Deterville Libraire, Paris. https://doi.org/10.5962/bhl.title.49223

Machatschke J.W. 1970. Rutelinae: synonymische bemerkungen. The Entomologist's Monthly Magazine 105: $157-158$.

Machatschke J.W. 1972. Scarabaeoidea: Melolonthidae, Rutelinae. Coleopterorum Catalogus Supplementa 66: 1-361.

MacLeay WS. 1819. Horae entomologicae: or, Essays on the Annulose Animals. R. and A. Taylor, London. https://doi.org/10.5962/bhl.title.65809

Ohaus F. 1905. Beiträge zur Kenntniss der amerikanischen Ruteliden. Stettiner Entomologische Zeitung 66: $283-329$.

Ohaus F. 1912. Hoplognathus bahianus n. sp. (Col. Rutel.). Deutsche Entomologische Zeitschrift 1912: 650 .

Ohaus F. 1914a. Neue Coleoptera lamellicornia aus Argentinien. Deutsche Entomologische Zeitschrift 1914: 299-304.

Ohaus F. 1914b. XIV. Beitrag zur Kenntnis der Ruteliden. Stettiner Entomologische Zeitung 75: 138156. 
Ohaus F. 1915. XVI Beitrag zur Kenntnis der Ruteliden (Col. Lamell.). Deutsche Entomologische Zeitschrift 1915: 256-260.

Ohaus F. 1918. Scarabaeidae: Euchirinae, Phaenomerinae, Rutelinae. In: Junk W. \& Schenkling S. (eds) Coleopterorum Catalogus 66: 1-241. W. Junk, Berlin.

Ohaus F. 1934. Coleoptera Lamelicornia fam. Scarabaeidae, sub. Rutelinae. In: Wytsman P. (ed.) Genera Insectorum 199a: 1-172.

Ratcliffe B.C. \& Jameson M.L. 1989. A synopsis of the genus Areoda (Coleoptera: Scarabaeidae: Rutelinae). The Coleopterists Bulletin 43: 135-144.

Manuscript received: 4 August 2020

Manuscript accepted: 8 June 2020

Published on: 24 August 2021

Topic editor: Nesrine Akkari

Section editor: Max Barclay

Desk editor: Pepe Fernández

Printed versions of all papers are also deposited in the libraries of the institutes that are members of the EJT consortium: Muséum national d'histoire naturelle, Paris, France; Meise Botanic Garden, Belgium; Royal Museum for Central Africa, Tervuren, Belgium; Royal Belgian Institute of Natural Sciences, Brussels, Belgium; Natural History Museum of Denmark, Copenhagen, Denmark; Naturalis Biodiversity Center, Leiden, the Netherlands; Museo Nacional de Ciencias Naturales-CSIC, Madrid, Spain; Real Jardín Botánico de Madrid CSIC, Spain; Zoological Research Museum Alexander Koenig, Bonn, Germany; National Museum, Prague, Czech Republic. 